\title{
A Prisoners' Island: Teaching Australian Incarcerated Students in the Digital Age
}

\author{
SUSAN HOPKINS AND HELEN FARLEY
}

University of Southern Queensland, Australia

\begin{abstract}
While incarcerated students have always faced many obstacles to full and effective participation in university study, the global shift toward paperless e-learning environments has created new challenges for prisoners without direct internet access. Based on prison focus groups with Australian incarcerated students and direct participant observation while tutoring tertiary students within four Queensland correctional centres, this paper explores the obstacles and constraints faced by incarcerated students in light of the increasing digitisation of materials and methods in higher education. This paper also reviews the outcomes, limitations and challenges of recent Australian projects trialling new internet-independent technologies developed to improve access for incarcerated tertiary students. This paper argues that technology-centred approaches alone will not adequately address the challenges of access for incarcerated students unless such interventions are also informed by an understanding of the sociocultural nature of learning and teaching within correctional centres.
\end{abstract}

Keywords: Incarcerated students; tertiary preparation; distance learning; digital inclusion.

Introduction: Doing Time Disconnected

Higher education in Australia has seen a radical shift over the past ten years toward digital, online teaching and learning management systems. Moreover, in recent years Australian universities have moved from technology-enhanced delivery to technology-centred delivery models, not only to promote economic efficiencies but supposedly to promote a more open, flexible and accessible learning environment. The University of Southern Queensland (USQ), which has a long history in the provision of distance education for incarcerated students, has set a deadline of early 2015 to transfer all learning objects to paperless, digital and online only delivery. This digital shift away from the traditional and expensive practice of posting printed course materials has, however, produced some unintended effects for economically and geographically disadvantaged students. The majority of incarcerated students in Australia still have no direct access to the internet and they remain, perhaps, the most marginalised and underrepresented group in Australian tertiary education (Huijser, Bedford \& Bull, 2008). While they often succeed in tertiary study, despite considerable constraints and typically low levels of secondary school attainment, prisoners remain the disconnected, invisible and silent members of the much valorized online student communities of contemporary higher education. Despite concerted attempts by Australian governments to address equity and access issues in Australian higher education over the past decade, including the national equity policy framework, little progress has been made for incarcerated students who are also typically from low socioeconomic backgrounds.

As Australian and international research has suggested, criminal 'justice' reproduces an inherent class bias and prisons are overwhelmingly populated by the poor, the marginalised, the unemployed, the uneducated and the inheritors of extreme socioeconomic disadvantage (Australian Bureau of Statistics, 2013; Reiman \& Leighton, 2010; White \& Perrone, 1997; White \& Graham, 2010; Vinson, 2004; Vinson, 2007). In some cases the digitisation of tertiary education has inadvertently exacerbated the social and cultural isolation of incarcerated students. Moreover, while both public and private Australian prisons support education in principle as a pathway to self directed rehabilitation, in practice the overriding emphasis on security and community safety prevents inmates from accessing the internet, social media and email. Access to computer hardware and storage media is also problematic, especially for 'protection' prisoners in very high security environments. Against a wider political backdrop of economic rationalist imperatives of doing more with less and utilitarian, instrumental priorities of building basic skills, some incarcerated tertiary students may not be permitted to study full time and those who do study must rely on increasingly over worked Education Officers to access information on their behalf (Huijser, Bedford \& Bull, 2008; White \& Perrone, 1997). As White and Perrone (1997, pp. 213-214) suggest, while Australian corrective services generally support progressive programs in principle, on the ground they tend 
to run into the uncomfortable realities of cost cutting, lack of staff and security issues. Moreover, while access to technology mediated learning varies greatly across the nation's six states, two territories and one hundred correctional centres, Australian incarcerated tertiary students as a group are routinely denied even the minimum standards of communication promised by the open and inclusive Digital University.

This paper aims to bring these complexities and contradictions to light with a particular focus on projects initiated by the University of Southern Queensland trialling internet alternatives and digital resources in Queensland correctional centres. Teaching incarcerated tertiary students in particular unearths underlying tensions in contemporary higher education and challenges traditional assumptions about digital and social inclusion, participation and access.

\section{Whose Rehabilitation: Methodology and Theories}

This paper is based on the researchers' direct experiences of tutoring incarcerated University of Southern Queensland (USQ) Tertiary Preparation Program (TPP) students inside Australian prisons over a two year period while trialling new mobile e-learning technologies and digital resources such as handheld eBook readers (eReaders) and Stand Alone Moodle (SAM) internet simulations loaded with USQ TPP course content and readings. In order to make sense of the layers of social, cultural and political complexities and contradictions surrounding contemporary Australian prison education, qualitative research methods were selected. The study involved 74 incarcerated participants studying a tertiary preparation or bridging program within five prisons in Queensland, Australia. Data sources for this study were five sixty minute audio taped focus group interviews with incarcerated students enrolled in the University of Southern Queensland's Tertiary Preparation Program and regular fortnightly field notes from direct participant observation while visiting and teaching USQ TPP students face to face in four of the five targeted Queensland correctional centres. Tertiary Preparation Program students were also encouraged to keep a regular study journal for the purpose of reflecting on their study experiences including their goal setting, time management and obstacles and constraints they encountered while completing the program. Rights to withdraw without penalty, confidentiality and anonymity were provided to all participants and permission was sought to record the focus group discussions, which addressed the students' experiences of tertiary education generally and use of trial learning technologies in particular.

This data was interpreted in the light of sociocultural theories of learning as it soon became evident emerging problems and project pitfalls were related not just to the level of technical competence of users and technological issues with failing eReader devices, but rather were intertwined with the social, cultural and affective climate of Australian correctional centres. Sociocultural theories recognise that social interaction is fundamental to effective teaching and learning (Vygotsky, 1978; Wertsch, 1985; Northedge, 2003) even and especially in the context of electronic learning environments (Warschauer, 1998; Hung \&Yuen, 2010). Hence quality policies, projects and programs must cultivate critical awareness of contextual factors and the influence of sociocultural variables on teaching and learning (Warschauer, 1998; Hung \&Yuen, 2010). Moreover, the actual use of technologies in any education context will inevitably be constrained by sociocultural factors such as the culture of the institution, the beliefs and attitude of staff and the overriding role of the institution (or prison) in social reproduction and control (Warschauer, 1998). Similarly, whereas more instrumental, technocratic and traditional approaches to prison education assume it is the individual prisoner/ student that must be rehabilitated, a sociocultural approach suggests it may be the wider social and cultural environment that is in need of reform. Following Luke (2003) and his application of Freire's (1970) insights into how systems of representation reflect economic and social power, this paper suggests prison education is also a necessarily political matter. As a result, pedagogical and technological interventions and 'solutions' must not only use contextual and sociocultural data and analysis, but recognise the speaking positions of marginalised groups who are, in their own way, 'talking back against power' (Luke 2003, p. 133).

As both academic researchers and active participants in the teaching and learning process with incarcerated students, we quickly learned that if we wanted to facilitate authentic digital inclusion we would need to do more than distribute mobile learning devices and provide training in ICT skills. We would need to listen to the stories students wanted to tell, allow incarcerated students a voice for relaying their experiences and reflect on the common themes that emerged about the unique problems incarcerated students deal with on a daily basis - problems that define and delimit the most innovative and well intentioned of technological interventions. Following the insights of critical pedagogies (Luke 2003; Freire 1970), we believe it is important to give voice to students and recognise the themes and issues the students themselves have identified as important. This is especially critical for incarcerated students who are unavoidably absent from online discussion forums and surveys and remain the silent and invisible 'other' in much mainstream education research. In the main, the incarcerated students in our study were highly motivated to be heard and to educate us about the conditions under which they study. Overall they proved articulate and insightful observers of their own learning experiences and environment. The issues that rose to the surface of focus group discussions and of everyday teaching and learning were not technocratic concerns or rationalizations but rather very human questions of identity, personal history, subjective experiences, social connectivity and being 'seen' as a 'person'. Hence this paper is not about technology per se or even access to technology alone, but rather re- 
views the limitations of new learning technologies in the social, cultural, political and invariably human environment of the prison.

\section{Project Background: Incarcerated Students and Internet Alternatives}

In order to address the increasing diversity of student cohorts and the needs of isolated and incarcerated students in particular, the University of Southern Queensland (USQ) has recently developed internetindependent digital learning technologies that allow students to access a modified version of the university's electronic learning management system without accessing the internet. The University of Southern Queensland's Australian Digital Futures Institute (ADFI) and USQ's Open Access College (OAC) are working in partnerships with Queensland Corrective Services (QCS) and Serco Asia Pacific, operators of Southern Queensland Correctional Centre (SQCC), in the ongoing development and deployment of new mobile learning technologies, trialling handheld eBook readers (or eReaders) and Stand Alone Moodle (SAM) internet simulations to improve access and develop digital literacy skills for incarcerated students. In 2013 USQ course materials including study books and course readings were loaded onto $47 \mathrm{eBook}$ readers distributed to five Queensland Correctional Centres and a version of the 'Study Desk' (USQ's online learning management system) was installed on the SQCC education server each semester across 2012/2013/2014. The course selected for use during the ongoing trial of these e-learning technologies in prisons was TPP7120 Studying to Succeed from the University of Southern Queensland's Open Access College Tertiary Preparation Program (TPP).

\section{Project Background: The Tertiary Preparation Program (TPP)}

The USQ OAC Tertiary Preparation Program (TPP) specifically targets low socioeconomic status groups disadvantaged by both social and economic positioning and by the Australian tertiary entrance system of competitive ranking. The TPP is essentially a second chance program founded in the belief that tertiary entrance scores do not necessarily measure merit or potential and tertiary preparedness can be provided through bridging programs and alternative pathways. Successful completion of the TPP provides guaranteed entry to USQ undergraduate programs and to many other programs offered by Australian universities. For incarcerated students in particular, who are typically early school leavers with poor levels of formal education, the tertiary preparation program is not merely an alternative pathway to a degree but also an opportunity to chart a new life course:

I never passed year 8 so I want to use my time wisely in jail. And get better qualified when I get out. (incarcerated USQ TPP student, 2013)

I went off the rails a bit when I lost my job and then lost my Mrs. It all went downhill. I was drinking too much and trashed the local cop car. I got pinched and then I got parole. I was working but once they found out I was on parole they sacked me. I've been for a few interviews but there's no job once you say you're on parole. It's more about money than anything else. It all comes down to money at the end of it. When I finish the TPP I'm going to study Business. I want to run my own business and my own life and be my own boss this time. (incarcerated USQ TPP student, 2013)

At night I can't study because I have really heavy medication but I usually study in the afternoon. I've got my own cell. It's quiet and when I can sit down and concentrate on what I'm doing I quite enjoy it. I found it as an opportunity to redeem myself with my education. I really enjoy learning again. (incarcerated USQ TPP student 2013)

I find that keeping myself busy and my mind active helps me to keep myself focused on my future. I find studying is giving me the necessary skills to overcome this problem by boosting my self-esteem and by giving me my self-worth but while in solitary confinement I had no access to my study materials and have fallen behind. (incarcerated USQ TPP student, 2012)

The pedagogical framework of the TPP supports the development of the individual as a self-managing student who takes responsibility for his or her own learning, sets and achieves personal life goals and develops a coherent life plan (Huijser, Bedford \& Bull, 2008). The program, which includes a careers development component, aims to develop not only essential academic skills but also the social and cultural capital, self -esteem, confidence and motivation, necessary for tertiary study success. Partly as a result, the TPP bridging program has had considerable success in attracting incarcerated students and enrols in excess of 200 inmates each year across 56 correctional centres throughout Australia. There are also currently over 100 incarcerated distance education students enrolled in degree level study (principally in Business, Engineering, Arts and Human Services) at USQ, with the majority gaining direct access to their undergraduate program through completion of the TPP pathway. Prison enrolment numbers in the USQ TPP continue to grow, especially in New South Wales and Victoria. Since 1989 the Tertiary Preparation Program has been offered as a print-based course for incarcerated students who are provided with hard copies of all study materials free of charge. Unfortunately, however, many of the tertiary undergraduate courses they wish to enter upon successful completion of the TPP program are now almost entirely online and cannot be completed without access to the Internet. Against this backdrop of increasing digitisation of tertiary programs, prison education runs the risk of being once again relegated to isolationism and disconnection.

\section{A Prisoners' Island: The Cost of Isolationism}

There is a long-standing colloquialism that encapsulates the sociocultural perspective on life and learning: 'No man is an island.' In other words, all men and 
women are determined or at least shaped by social interaction, sociocultural variables and their social and cultural environment. Certainly, in this contemporary digital age of time-space compression delivered by new communication technologies, most of the developed world's population has never been so well connected in a multiplicity of ways. As Castells (2004) has pointed out, we are living in the twenty-first century 'Network society' whose power relations work on a binary logic of inclusion and exclusion. It follows, the powerless underclass in such an environment are invariably marked and profoundly affected by isolation, exclusion and disconnection; a truly cohesive and inclusive society must facilitate connectivity, cooperation and engagement through virtual networks for the most marginalised communities, including the incarcerated.

Australia, settled as a British prison island in the $18^{\text {th }}$ century, has new national identities today shaped by the global flow of information and culture and new forms of social organisation built on the accumulation of contacts and capital through digital networks. The Australian prison, however, is still a metaphorical 'island' in the sense that the incarcerated are currently cut off from the fast paced mediated network of information and social exchange accessed by the rest of the population. Currently there are 30,775 prisoners held in Australian correctional centres, (with incarceration rates on the rise, especially for women and Aboriginal and Torres Strait Islander peoples) and the vast majority come from backgrounds of low family income, lack of postschool qualifications, limited education, and limited computer use/internet access (Australian Bureau of Statistics, 2013; Vinson, 2007; Vinson, 2004; White \& Perrone, 1997; White \& Graham, 2010). As Huijser, Bedford and Bull (2008) have pointed out, most prisoners in Australia enter the prison with a low level of social capital relevant to the rest of the population and this social marginalisation is exacerbated by the period of ICT disconnection during incarceration, which for most prisoners is at least two years. Moreover, this social and cultural isolation in turn increases the likelihood of further alienation, unemployment, poverty and recidivism or reoffending (Huijser, Bedford \& Bull, 2008; Reiman \& Leighton, 2010). While incarcerated, offenders are literally and metaphorically 'disconnected' from the digital society and economy and subsequently are not adequately prepared for productive and engaged digital citizenship upon their release.

The incarcerated USQ TPP students who participated in this e-learning trial were acutely aware that it is part of their punishment to be cut off, without access to 'smart' phones, tablets or other internet enabled mobile devices, from the networked online and instant communication of the contemporary, digital or (post)modern world. Indeed their sense that the social and cultural world was moving on without them was one of the most frequently mentioned 'pains' of their imprisonment. In our 'enlightened' networked digital age, this enforced social and cultural isolation is perhaps the most severe and debilitating of punishments:
It's so hard to plan ahead in here. At home you can just jump on the net and you're there. Its information I crave in here. (incarcerated USQ TPP student 2013)

Do you know what the first thing I'm going to do when I get out of here? Check my email and face book! (incarcerated USQ TPP student 2013)

I like getting on the computer and searching when I do research. In here I found the information limited in books. It would be a lot easier to study if I had the internet to search. It gives you a lot more information. There's only a limited number of computers and its hard trying to get access to computers. It really is an access issue - access to information and access to help. When I did TPP last time outside I was working as a carpenter and I did it at night. I used to email somebody if I got stuck. You could email the tutors and there was the online forum where students could chat to each other. It's a lot more difficult to study inside, trying to find time when you can study and getting motivated in that time. It's more difficult to stay motivated here than outside. (incarcerated USQ TPP student, 2013)

As higher education researchers (Watts, 2010; Pike \& Adams, 2012; MacGuinness, 2000) in the UK have pointed out, education is often a 'lifeline' or survival strategy which enables student-inmates to cope with the 'pains,' or subjective experiences of imprisonment. In prison, education does much more than improve employability; it is a valuable tool to deal with time, isolation, psychological instability and the loss of personal autonomy (MacGuinness, 2000; Watts, 2010; Pike \& Adams, 2012). In this study, USQ TPP incarcerated students frequently disclosed the emotional hurdles and experiences of depression, detachment, victimisation and apathy that had, at times, derailed their study schedules:

The mental aspect. The loss. You think about how it's going to impact your life. You try to stay positive. But you wake up and you're still here. (incarcerated USQ TPP student, 2014).

Prison is a waste of time. With education at least you can say you've done something with your time. But there's no real reform or reprogramming. You're just locked away. (incarcerated USQ TPP student, 2014)

In the artificial, closed or 'total' institution of the prison, inmates lose the capacity to manage their own space and time subject to the institutional operational priorities of security, regulation and control through isolation (Goffman, 1990; Wilson \& Reuss, 2000; Reuss, 2000; Watts, 2010; Pike \& Adams, 2012). This dehumanising process is at odds both with education programs such as the TPP which aim to develop the student's autonomy, self-management and selfdetermination and with the modern correctional system's own aims of facilitating self-development and rehabilitation. International research suggests more complete rehabilitation, which moves subjects from passive prisoners to active empowered agents, may require providing prisoners with more responsibility, 
choices and a limited degree of internet access for employment services and e-learning (Axelsson, 2013; Pike \& Adams, 2012). In the United Kingdom, internally networked 'closed internet' learning management systems have been recently trialled to simulate a 'virtual campus' for incarcerated students in targeted correctional centres. These UK trials have been criticised, however, by Open University academics as mostly inadequate and unsatisfactory alternatives to authentic networked learning and communication (Pike \& Adams, 2012; Pike cited in Pike \& Adams, 2012; Seale cited in Pike \& Adams, 2012). As Pike (cited in Pike \& Adams, 2012) and Pike \& Adams (2012) have pointed out, if technology in prisons is to be used more for reform rather than control, true learning networks or learning communities of like minded individuals, even small informal study groups, need to be further encouraged and supported. This may be because, as previously discussed, learning is always a social process and knowledge itself 'arises out of a process of discoursing, situated within communities' (Northedge, 2003, p. 19).

Our Australian experience with internet simulations also suggests learning technology cannot just be engineered and inserted into the correctional centre, or 'bolted on' to the unreconstructed prison, and expected to work effectively and efficiently. Technology cannot replace social interaction; it can only support it. Moreover, the mere presence of innovative, mobile and digital learning technologies cannot improve access if the people on the ground and their social-political and cultural-discursive practices are unwilling or unable to support it. The prison 'voices' documented in this paper are an attempt to chart what is working and what is not working in incarcerated digital learning in Australia, from the student's perspective, and to 'flesh out' these issues in the process. Acknowledging and understanding the social-political and cultural-discursive barriers faced by incarcerated adult distance education students is critically important to the long term success of such e-learning initiatives.

\section{Learning Offline and Behind Bars}

While key stakeholders have invested in the exciting potentialities of new learning technologies, security constraints, cultural constraints and a lack of staff and funding mean incarcerated students still do not have equitable access to learning resources. Our research with incarcerated USQ TPP students parallels the observations of practitioners and researchers in the United States and the United Kingdom who have documented the formidable obstacles faced by incarcerated postsecondary students (Watts, 2010; Pike \& Adams, 2012; Meyer, Fredericks, Borden, \& Richardson, 2010; Wilson \& Reuss, 2000; Reuss, 2000). As Watts (2010, p. $60)$ observes, prisons are often stressful, noisy, disorientating and depressing places not conducive to studying, concentration and motivation. Similarly, Pike \& Adams (2012, p. 389) refer to the 'desolate landscape' of the 'working' English prison, where students on a strict working schedule are often unable to find adequate study time, space or technology during the day and may only study in the evenings in their cells.

The European Prison Rules based on the United Nations Standard Minimum Rules for the Treatment of Prisoners stipulate that prisoners who take part in education during working hours shall be remunerated as if they had been working and thereby suffer no financial loss for attending education instead of work. Most Australian states, however, are following the AngloAmerican model of increasing privatisation and funding cuts to the public sector, which means in effect, tertiary education may be sidelined by industry work, and training for industry. Moreover, in some prisons and some states this means incarcerated university students receive less pay than prisoners who work in industry, if they have the opportunity to undertake tertiary study at all. The lower priority given to tertiary study is evident in the (lack of) time, space and technology allocated to incarcerated university students.

In our Australian focus group discussions, incarcerated USQ TPP students consistently complained of a lack of access to quiet spaces, education staff, education facilities and electronic resources and (a perceived) lack of cooperation from custodial correctional staff. Contrary to the popular misconception that prisoners have unlimited time on their hands, almost all incarcerated USQ TPP participants identified a lack of quality study time as a significant constraint due to their assigned employment hours, tightly structured timetables and frequent lock downs, disruptions and dislocation. In the words USQ TPP incarcerated students:

It is not possible to know the constraints we face every day while in custody. I would face things like lockdowns, cell searches, head counts, and various other things every day. I felt constant pressure trying to meet my due dates and study schedule. (incarcerated USQ TPP student, 2013).

The resources are not available and because there's smaller numbers in protection there's no help from other students. I wasn't able to connect. There's only one computer - it's the dinosaur age in here! (incarcerated USQ TPP student, 2013)

Unfortunately, I have no computer, no lecturer, no tutor... I can do so much better. (incarcerated USQ TPP Student, 2012).

There are situations that occur in here that result in the facility being locked down. This can extend from a few hours to weeks...the USQ tutors are not permitted into the centre. There is no access to the centre's education officer and no access to the postal system. (incarcerated USQ TPP student, 2013)

There is a subculture in prisons where you get shunned or pushed aside for studying and being an academic - people don't want to talk to you. There are groups and groups within groups. You can't present yourself as being a step-up from anyone else. They won't always let a tutor in anyway, especially in Secure. The anti-academic culture is very strong in Secure. (incarcerated USQ student and peer tutor 2013).

I'm sharing a cell so there's not much room to study. The atmosphere makes it hard to study. We are dou- 
bled up and they have the TV on when I'm trying to study. (incarcerated USQ TPP student 2013).

Against such a backdrop there are limits to how effective new communication and e-learning technologies alone can be in terms of improving learning outcomes for incarcerated students. Despite decades of reform and policies and strategies supporting education for the incarcerated, the $21^{\text {st }}$ century prison is not necessarily a fair or efficient learning environment. Moreover there is a growing gap between how the twenty first century prison is represented and the reality experienced by the students inside.

\section{Reality Checks: Hard Lessons for Incarcerated E-Learning}

In order to facilitate the development of digital citizenship and digital literacy skills for incarcerated students and to support the transition to digitised course materials, over 201347 eBook readers were distributed to USQ TPP students across five Queensland correctional centres. Concurrently, the eBook readers project manager (and lead author of this paper) visited four of the five targeted correctional centres on a regular rotation to deliver tutorial support to USQ TPP students, provide training on the eBook readers and to gain a better understanding of USQ TPP incarcerated students and the challenges they face. During this trial a number of problems were identified with the eBook readers that impacted on the students' engagement with this particular form of mobile learning technology.

While the light and mobile handheld digital eReader could, theoretically, allow the student to study anywhere, anytime, the majority of incarcerated students in this trial preferred their old heavy hard copy texts and still preferred holding a printed book in their hands to read it. Active and focused reading for scholarly purposes (as opposed to the recreational reading the BeBook Pure e-readers were originally designed for) requires highlighting or making notes on the text. The BeBook Pure handheld digital device, selected in the main because it conformed to stringent Queensland Corrective Services security requirements, did not provide these functions and could not replicate all the aspects of traditional study with printed text books. The TPP7120 course also requires moving back and forth across multiple pages and multiple study books. The digital eReaders frustrated this necessary process as the user cannot minimise a window to move quickly and seamlessly between documents. Not being able to take notes and eReaders freezing or being too slow to move pages were the most common practical impediments identified by incarcerated students in the trial. A number of the students complained that they would have preferred personal lap top computers loaded with their course content; however, incarcerated TPP students were not permitted personal lap top computers by the prison(s) at the time of the trial. Unlike computers, the eReaders are not backlit. Although under normal circumstances this is an advantage as it allows for long periods of reading without eye strain, in the environment of the prison, when students wanted to read after 'lights out' this was viewed as another limitation of the device. When compared to personal computers, 'smart' phones and other mobile devices, the eReaders, once loaded with large TPP course content files and other learning objects, were relatively slow to load, which the incarcerated participants found frustrating. While students on the 'outside' have the option of printing out electronic documents (usually at their own expense), incarcerated students reported that they either did not have access to a printer or that could only print a limited number of pages through a request to their education officers. The lesson learned in this trial suggests that technology which may serve its purpose in one educational context will not necessarily function effectively in the unique prison environment. Moreover, postsecondary educators must be sensitive to the particular limitations of this alien and alienating prison environment to adequately address the increasing diversity of student cohorts. By giving voice to the prisoners who participated in our e-learning trial, it is hoped this paper will contribute to this ongoing endeavour.

On a practical level, the Australian USQ eReader trial confirmed that incarcerated students require 'online' personal computers rather than handheld digital readers. As Australian prisoners have no access to online computers and this is unlikely to change in the near future, a portable version of USQ's LMS Moodle was deployed to replicate USQ's online learning environment for incarcerated students enrolled in the Tertiary Preparation Program. At SQCC, a privately operated Queensland prison, students were invited to trial the USQ Stand Alone Moodle (SAM) internet simulation loaded onto desk top computers available in a computer room of the prison's education block. In this instance problems and contradictions apparently arose in terms of students' access to the computer room:

I spent a couple of hours on the Moodle every week. I enjoyed working with the Moodle. The Moodle was almost like being on the internet. Unfortunately not everything was loaded onto the Moodle, there are still a lot of readings missing. It was frustrating at times too when we were denied access to the com-

puters. (incarcerated USQ TPP student 2013).

The problem you have in jail is getting access to the room. We're only allowed to use the computer room four hours a week...and you have to type your assignment in that time too. (incarcerated USQ TPP student, 2013)

Some people give up if it's too frustrating. In here we have to use our own initiative or persistence to keep going. Officers won't let you out the gate if you're not on the list so sometimes I have to risk a breach to get to the computers lab or to the education officer if there is a problem. (incarcerated USQ TPP student , 2013)

Even when provided with regular training and support to develop their digital literacy skills, some incarcerated participants regularly resisted both the handheld digital eReaders and the SAM computers, consistently expressing preference for printed hard copy text:

I would rather use the hard copy. I don't even like 
using the computer to do my assignments. I'd rather write by hand. I work better at night anyway. (incarcerated USQ TPP student, 2013)

I have been incarcerated for a substantial period of my life. There is almost no technology in correctional centres, so the eReader was as foreign to me as the outback is to an Eskimo. (incarcerated USQ TPP student, 2013)

I don't use the computer much because I don't have a lap top and I prefer to work alone in my cell. (incarcerated USQ TPP student, 2012)

I don't really use the computer that much. If I had a laptop I'd use it. I'd use it in me cell...I'm not comfortable sitting around people all the time. We don't get very much privacy in here. When you've been in jail all your life and you've got another twenty years to go you're more comfortable in your cell. It's funny because you're locked away from everybody but you just want to lock yourself away. I prefer to do everything by hand - unless they gave me a lap top. (incarcerated USQ TPP student, 2012)

In the everyday life of a prison, 'movement' is a big issue and frequent disruptions where students can be moved without warning or confined to their cells mean that prisoners classified as 'students' will not always have reliable access to education staff and education facilities. While it is to be expected that operational goals of security and order will be the greatest priority on the part of prison administrators, from the perspective of the students themselves there is still currently not enough time, space or access to the right technology to provide fair and equitable higher education for incarcerated students. Higher level learning in particular requires not just IT skills, but student-centred, holistic learning environments wherein students have some level of control, consistency and predictability over their study schedule and learning experiences. As Pratt (1993) and Knowles (cited in Pratt 1993) have pointed out, self-direction and the self-concept of the learner are vitally important concepts in andragogy. Moreover, as researchers and practitioners in this relatively uncharted environment we need to be sensitive to the identity investments and subjective experiences of incarcerated students, recognise the role of emotions such as fear, apathy, detachment and depression in this trial and respect that some incarcerated students may prefer to work alone in the relative privacy and security of their cells. Hence the problems faced by incarcerated students as complex social beings coping with a relatively hostile social and cultural environment mean prisoners may not respond to learning technology in the same ways as other tertiary students. Clearly 'access', in this environment, does not always mean use.

\section{The Human Element: Making a Connection}

Despite their common frustrations with the new digital learning technologies, the one element of the Australian USQ TPP trial almost all participants seemed positive about was receiving regular visits from university lecturers and tutors. Even and especially when things were going wrong with the technology, partici- pants appreciated the embodied presence of the university teacher to encourage, coach and confirm their own experience as a university student. After all, the good teacher does what the computer cannot, which is recognise them as people (whole, complex social beings) and provide an element of empathetic humanity and social connectivity in a relatively inhospitable and isolated learning environment. As Pratt (1993) and Knowles (cited in Pratt 1993) have suggested, effective andragogical approaches require an element of relationship building and establishing a climate of mutual respect, trust, collaboration and humane treatment. It is the responsibility of the adult educator to provide a social learning environment, not just content and technologies in isolation, and this is especially important for incarcerated students who often have complex needs and multiple disadvantages. Certainly the incarcerated USQ TPP participants valued and appreciated face-to-face time with 'real' lecturers and tutors over and above digital simulations:

Having university lecturers visit prisons is a great way to combat the isolation incarcerated students feel while studying. I noticed the visits also helped to keep a few student motivated and continue with their studies instead of dropping out of the course. (incarcerated USQ TPP student and peer tutor, 2013)

The information we receive from the tutor face to face is the difference in pass or fail, understanding or having no clue...The help from the USQ tutors was the most vital aspect of my study. I guess I learn better when somebody shows me. (incarcerated USQ TPP student, 2013)

The biggest thing that helps is having the uni lecturer come in for a visit, so you get to see who is marking your paper and that they are a real person. (incarcerated USQ TPP student, 2013)

I left school at 13. I need face to face help with the course. Last semester the tutor couldn't get in. Like most people I need help from a person especially with the advanced maths. (incarcerated USQ TPP student, 2014)

Regular teaching visits also enabled the researchers in this study to move beyond the 'academic tourist' (Reuss, 2000) position of prison focus group facilitator to the (imagined) more trustworthy position of academic coach. In turn, this enabled us to draw a deeper and more sensitive appreciation of the specialised needs, experiences and perspectives of incarcerated tertiary students. Incarcerated students in particular seem to have an acute need to know the 'real person' and be known as a 'real person', that is, a person with multiple identities, life stories and potentialities. As Reuss (2000) warns, it is a mistake to imagine one can swoop in and 'rehabilitate' through expert technocratic training when effective prison projects require building trust, empathy, tact and diplomacy. Putting the right technology in place is only part of the solution, the real issue is what the student $i s$, or aspires to be:

It's not just about telling prisoners about what university courses are available. It's about making them 
believe it's actually possible. I never thought I could do a university course. I thought uni was only for smart people and rich people. (incarcerated USQ student, 2013)

Like many other non traditional and low socioeconomic status students, incarcerated students face barriers to higher education participation which include both financial and social and cultural factors such as a lack of confidence and self-belief. Thus far, however, Australian correctional education has tended to focus mostly on providing basic skills rather than raising the aspirations of prisoners, like any other marginalised and underrepresented group, toward higher education participation. Australian prisoners may be underrepresented in higher education because on a culturaldiscursive level they frequently regard it as beyond their reach and on a material-economic level it is not adequately supported with resources on the ground. Moreover on a social-political level it appears some Australian prisoners are actively discouraged from undertaking university study to be channelled toward industry and vocational training (in the name of employability) due to ascendant economistic, utilitarian and neoliberal values. These implicit priorities and 'practice architectures' (Kemmis, McTaggart \& Nixon, 2014) of the contemporary prison are reflected in the management of movement, time and space:

Prison is an environment where it is especially difficult to remain focused. This constraint is made up of a number of factors such as it being noisy, regimented and there being a lack of a supportive peer group...a greater emphasis is placed on employment, than on education. (incarcerated USQ TPP student, 2012).

I find it hard to find time to do TPP study with balancing work and the other courses we have to do in here. (incarcerated USQ TPP student, 2012).

In industry you have the one session from 9am to $11.45 \mathrm{am}$ - then lunch, then the second session from $1.00 \mathrm{pm}$ to $3.45 \mathrm{pm}$ - same thing day in, day out. Metal shop or wood shop is pretty much the only choice. Usually only a long term person might get to learn new skills. (USQ TPP incarcerated student, 2014)

They won't let me off work and I am trying to do year ten at the same time, it doesn't leave much time for TPP (incarcerated USQ TPP student, 2012).

The officers say to me, 'I had to study and work at the same time so you should too.' (incarcerated USQ TPP student, 2013).

They won't schedule me as a full time student. I wrote a letter about it. But they say in the real world you have to work and study at the same time so I should have to do that in here too. What they don't understand is that in the real world you get access to computers and the internet 24/7. You don't get locked down at $6.30 \mathrm{pm}$ and unlocked at $7.30 \mathrm{am}$ for work. I am on meds [sedative medication] at night so I can't study at night. And up in the unit it's really hard to study with people being loud and knocking on the door. You never get time to your- self. Its better in the computer lab but I have to fill out forms and give 48 hours notice to get near the computers. I told them I want more study time. working here is not going to help me learn new skills. Just making fences - I already know how to weld and do all that. I'm a qualified mechanic and I worked in the mines doing everything for two years. But they said it would teach me punctuality. I would rather study so when I get out I can have a degree. (incarcerated USQ TPP student 2013)

\section{Student or Offender?}

The status or label of 'student' is particularly meaningful within prisons not only because it determines the inmate's schedule, allocation of time and relation to industry but also because it legitimates the inmate's construction of a new identity and life course (see Pike \& Adams 2012, p. 370; Watts 2010, p. 62). The identity of student becomes a marker the individual uses to distance himself (or herself) from the culture of the prison (see Pike \& Adams 2012, p. 370; Watts 2010, p. 62). As sociologists such as George Herbert Mead (1934) and Erving Goffman (1959) would point out, identities are not made in isolation - our sense of self is made through conversation with others in social interactions.

The USQ TPP staff teaching visits were especially important for the prisoners in part because it provided them with a fresh audience for their renewed identity and fledgling performance of 'university student' as well as an expert (and, in their eyes, relatively unbiased) other to legitimate that role. As Goffman (1959) would suggest, the power of this self-presentation and performance of selfhood lies in its social interactivity. The role of student requires the presence of the teacher, in some form, to interact with. The primacy of personal identity and social interaction is one of the unintended effects and learning outcomes of this e-learning in prisons trial although it emerged not from the technology per se but from the teaching and learning around it. While higher learning is a point of access for reflecting upon identity for many students, incarcerated students in particular seem to have a heightened awareness and appreciation of education as a source of (reinvented) personal identity, purpose and transformation (see MacGuiness, 2000; Wilson \& Reuss, 2000). This may be because by the time they enter the correctional centre their self narratives as 'delinquents', 'criminals' or 'offenders' have been shaped by the labelling processes of institutions, essentially turning them into objects rather than recognising them as subjects (Reuss, 2000).

In order for students to negotiate an alternative prosocial relationship to these major social institutions they need more than vocational training and basic skills; they need time and (both literal and metaphorical) space for self determination, social connectivity and holistic personal development (Wilson \& Reuss, 2000; Watts, 2010; Pike \& Adams, 2012). As Pike \& Adams (2012, p. 374) have suggested, correctional services need to take the self-identities of prisoners very seriously and support the 'student identity' which 
may provide purpose and meaning in the short term and facilitate successful resettlement in the longer term. Identity change must be part of the rehabilitative project because, as Reuss (2000) explains, truly transformative prison education must address the personal and life history of the prisoner. As Watts (2010, p. 62) has suggested, fostering this student identity is part of the teacher's responsibility and especially necessary in a prison where individuals are working to reform themselves and plan better lives. Moreover, as Ruess (2000) and Wilson \& Reuss (2000) have argued, truly transformative prison education must move beyond the utilitarian human capital model, with its focus on building skills for employability, to recognise both the inherent personal value of the learning process and the social value of education for empowerment. As the group most frequently disadvantaged by the intersection of class, race and social and cultural backgrounds, incarcerated students may be the forgotten and invisible 'equity' group of higher education, and the 'minority' group most in need of raised aspirations, personal development and enabling education.

\section{Conclusions}

Current Australian prison policy effectively exacerbates the social exclusion of the most marginalized groups in Australian society. Despite ongoing attempts to develop and trial modified digital technologies, the majority of prisoners in Australia still have no direct access to the internet and this digital, social and cultural disconnection undermines rehabilitation in a digital age. Policymakers must prioritise digital literacy and not just in limited terms of basic skills but in the context of participation in digital networks. One of the key findings of our research is that it is not the technology itself that matters, or even the content it carries, but rather it is contact or connectivity which incarcerated students want and need most. It is people and making connections with people which will drive the network society, both inside and outside the prison gates. Certainly our incarcerated students are requesting not just more access to technology but more access to interpersonal support and social exchange in a collaborative and humane learning environment. Over the past twenty years policy developments in Australian states have furthered an economic rationalist agenda which leads to staff and funding cutbacks. However, real rehabilitation requires funding for education officers and visiting academics to teach the 'whole' person and support them through the very human process of learning. It follows policymakers must value and recognize education's worth not only in economistic terms of employability but in humanistic terms of personal and social transformation and integration.

Ironically, it is the human element of this trial with modified learning technologies that is potentially the most powerful. Although regular university staff visits to correctional centres may not be economically viable in the long term or on a larger scale, the incarcerated participants in this study frequently attributed their study success not to improved access to technology but to improved access to and interaction with university teachers, peer mentors and other students in a consistent connected learning community. Thus far, increasing digitization through eReaders and intranets has not been entirely successful in facilitating independent selfmanaging learners; rather, incarcerated students are still seeking more support from the university in terms of access to staff and in terms of access to resources such as printed textbooks and lap top computers. When faced with the complex sociocultural environment of the prison and the complex psychosocial problems of incarcerated students, the solution therefore needs to be broad and sociological in orientation, looking beyond the narrow focus on new technology inserted into a new setting. Improving higher education for this specialised group will necessitate technological innovation; however it may also necessitate more face-to-face support and a renewed appreciation of the influence of social contexts and social connectivity in enabling education for marginalised and disconnected students.

\section{Acknowledgements}

The authors are very grateful to all the incarcerated students who participated in this study and to the education officers, custodial staff and general managers of Queensland Correctional Centres who facilitated our access to incarcerated USQ TPP students. We also wish to thank our partners, Queensland Corrective Services (QCS) and Serco Asia Pacific, operators of Southern Queensland Correctional Centre (SQCC) who provided access to USQ TPP incarcerated students and without whose support this study would not be possible.

References
Axelsson, L. (2013, October). What is the current situation within education and training in prisons in Europe. Paper presented at the 11th Biennial Conference of the Australasian Corrections Education Association (ACEA) Coogee Beach, New South Wales, Australia.

Australian Bureau of Statistics. (2013). Prisoners in Australia. Retrieved 14th April 2014 from:

http://www.abs.gov.au/AUSSTATS/abs@.nsf/ PrimaryMainFeatures/4517.0?OpenDocument

Freire, P. (1970). Pedagogy of the oppressed. New York: Seabury.

Goffman, E. (1959). The presentation of self in everyday life. London: Penguin.

Huijser, H. Bedford, T. \& Bull, D. (2008). Open CourseWare, global access and the right to education: Real accessor marketing ploy? International Review of Research in Open and Distance Learning, 9(1), 113.

Hung, H. \& Yuen, S. (2010). Educational use of social networking in higher education. Teaching in Higher Education, 15(6), 703-714.

Kemmis, S. McTaggart, R. \& Nixon, R. (2014). The action research planner: Doing critical participatory action research. Singapore: Springer.

Luke, A. (2003). Literacy and the other: A sociological approach to literacy research and policy in multilin- 
gual societies. Reading Research Quarterly, 38(1), 132-141.

MacGuiness, P. (2000). Dealing with time. In D. Wilson \& A. Reuss (Eds.). Prisoner education: Stories of change and transformation. Winchester: Waterside.

Mead, G. H. (1934). Mind, self, and society. Chicago: University of Chicago Press.

Meyer, S., Fredericks, L., Borden, C. \& Richardson, P. (2010). Implementing postsecondary academic programs in state prisons: Challenges and opportunities, Journal of Correctional Education, 61(2), 148-183.

Northedge, A. (2003). Rethinking teaching in the context of diversity. Teaching in Higher Education, 8(1), 17-32. Retrieved from http://www.tandfonline.com/ toc/cthe20/8/1

Pike, A. \& Adams, A. (2012). Digital exclusion or learning exclusion? An ethnographic study of adult male distance learners in English prisons, Research in Learning Technology, 20, 363-376.

Pratt, D. (1993). Andragogy after twenty-five years. In S. Merriam (Ed.). AdultLearning Theory: An Update (pp. 15-25). San Francisco: Jossey-Bass. Retrieved from http://www.academia.edu/3625772/ Andragogy After Twenty-Five Years

Reiman, J. \& Leighton, P. (2010). The rich get richer and the poor get prison: Ideology, class and criminal justice. Boston: Allyn \& Bacon.

Reuss, A. (2000). The researcher's tale. In D. Wilson \& A. Reuss (Eds.). Prisoner education: Stories of change and transformation (pp. 25-48). Winchester:
Waterside.

Vinson, T. (2004). Community adversity and resilience: the distribution of social disadvantage in Victoria and News South Wales and the mediating role of social cohesion. Richmond: Jesuit Social Services.

Vinson, T. (2007). Dropping off the edge: The distribution of disadvantage in Australia. Richmond: Catholic Social Services Australia and Jesuit Social Services.

Vygotsky, L. (1986). Thought and language. Cambridge, MA: MIT Press.

Warschauer, M. (1998). Online learning in sociocultural context. Anthropology and Education Quarterly, 29(1), 68-88.

Watts, J. (2010). Teaching a distance higher education curriculum behind bars: Challenges and opportuneties, Open Learning, 25(1), 57-64. doi: 10.1080/02680510903482256

Wertsch, J. V. (1985). Vygotsky and the social formation of mind. Cambridge, MA: Harvard University Press.

White, R. \& Perrone, S. (1997). Crime and social control. Victoria: Oxford University Press.

White, R. \& Graham, H. (2010). Working with offenders: A guide to concepts and practices. New York: Willan.

Wilson, D. \& Reuss, A. (2000). Prisoner education: Stories of change and transformation. Winchester: Waterside.

Dr. Susan Hopkins holds a PhD in social science and a Masters (Research) in education and is an Associate Lecturer within the Open Access College of the University of Southern Queensland, Australia. Dr. Hopkins teaches tertiary preparation program (TPP) students including incarcerated students. Her research interests include enabling education, digital learning and sociological approaches to the education of low socio-economic status groups, in particular incarcerated students.

Dr. Helen Farley is a Senior Lecturer within the Australian Digital Futures Institute of the University of Southern Queensland and a leading researcher in developing digital learning technologies for tertiary students without internet access including incarcerated students. 